\title{
Effect of grain particle size on energy values and chemical components of diets for Label
} Rouge broilers

\section{Heloisa Baleroni Rodrigues de Godoy, ${ }^{12^{*}}$ (i) Kênia Ferreira Rodrigues ${ }^{2}$ (iD Alessandra Gimenez Mascarenhas ${ }^{3}$ (D) Eder de Sousa Fernandes ${ }^{3}$ (D) Saullo Diogo de Assis $^{3}$ (D) José Henrique Stringhini ${ }^{3}$ (D)}

\author{
${ }^{1}$ Instituto Federal de Ciência e Tecnologia Goiano, (IF Goiano), 76300-000, Ceres, GO, Brasil. E-mail: heloisa.godoy@ifgoiano.edu.br. \\ ${ }^{*}$ Corresponding author. \\ ${ }^{2}$ Universidade Federal do Tocantins (UFT), Palmas, TO, Brasil. \\ ${ }^{3}$ Universidade Federal de Goiás (UFG), Goiânia, GO, Brasil.
}

\begin{abstract}
This study aimed to determine the apparent metabolizable energy (AME) and nitrogen-corrected AME (AMEn) values as well as the metabolizability coefficients of dry matter, protein, and ether extract of corn, pearl millet, and sorghum in different particle sizes for slow-growing broilers. Two experiments were carried out involving 280 chicks of the Label Rouge ${ }^{\circledR}$ Naked Neck broiler line, with 140 chicks allotted to each experiment in a completely randomized design. Treatments consisted of a reference diet and a test diet (60\% reference diet $+40 \%$ feedstuff). The feedstuffs were tested and particle size (expressed as geometric mean diameter [GMD, $\mu m]$ and geometric standard deviation [GSD], respectively) results were 816 and 1.73 for coarsely ground corn, 794 and 1.75 for finely ground corn, 1.517 and 1.92 for pearl millet grain, 760 and 1.63 for finely ground pearl millet (Experiment 1); and 1,866 and 1.86 for whole grain sorghum, 919 and 1.62 for coarsely ground sorghum, and 878 and 1.72 for finely ground sorghum (Experiment 2). A metabolism trial was conducted by using the total excreta collection method to obtain the AME and AMEn values as well as the metabolizability coefficients of dry matter, protein, and ether extract. The energy metabolization coefficient did not differ $(P>0.05)$ between the grains in the different tested particle sizes. However, there was an improvement in the metabolizability coefficients of dry matter, nitrogen, and ether extract as the particle size of corn was increased. In conclusion, larger grain particle sizes improve the metabolizability of nutrients and energy for slow-growing broilers. Whole-grain sorghum has limited nutritional utilization for slow-growing birds up to 21 days of age.
\end{abstract}

Key words: free-range broiler, metabolizable energy, particle size, Pennisetum glaucum, Sorghum bicolor, Zea mays.

Efeito da granulometria de grãos nos valores energéticos e componentes bromatológicos da dieta para frangos Label Rouge

RESUMO: Objetivou-se determinar os valores de energia metabolizável aparente (EMA), corrigida para o balanço de nitrogênio (EMAn), e os coeficientes de metabolizabilidade da matéria seca, proteina e extrato etéreo do milho, milheto e sorgo em diferentes granulometrias para frangos de crescimento lento. Foram desenvolvidos dois experimentos, com 140 pintos de corte da linhagem Label Rouge ${ }^{\circledR}$ Pescoço Pelado, distribuidos em delineamento experimental inteiramente casualizado. Os tratamentos consistiram em rações-teste (ração referência $60 \%$ + ingrediente 40\%) e uma ração referência. Foram testados os ingredientes e a granulometria expressa como Diâmetro Geométrico médio (DGM, $\mu \mathrm{m})$ e Desvio Padrão Geométrico (DPG): 816 e 1,73 para milho grosseiramente moido, 794 e 1,75 para milho finamente moído, 1,517 e 1,92 para milheto-grão e 760 e 1,73 para milheto finamente moído (Experimento 1); 1.866 e 1.86 para sorgo-grão, 919 e 1,62 para sorgo grosseiramente moído e 878 e 1,72 para sorgo finamente moído (Experimento 2). Os valores de AME e AMEn e os coeficientes de metabolização da matéria seca, proteina e extrato etéreo foram determinados pelo método de coleta total de excretas. O coeficiente de metabolização da energia não apresentou diferença $(P>0,05)$ entre os grãos nas diferentes granulometrias. Os coeficientes de metabolização da matéria seca, do nitrogênio e do extrato etéreo foram incrementados com o aumento da granulometria para o milho. O fornecimento de grãos com maiores granulometrias proporciona aos frangos de crescimento lento a melhora na metabolizabilidade dos nutrientes e energia. Grãos inteiros de sorgo tem aproveitamento nutricional limitado para frangos de crescimento lento até 21 dias de idade.

Palavras-chave: energia metabolizável, frango caipira, Pennisetum glaucum, Sorghum bicolor, tamanho de partícula, Zea mays.

\section{INTRODUCTION}

The use of different particle sizes and even whole grains in broiler diets has been stimulated as a way to reduce feeding costs and increase performance. The inclusion of whole grains beneficially affects gizzard and gastrointestinal development, since particles can compromise feed digestion and intestinal health (CHEWNING et al., 2012, FERNANDES et al., 2013; SINGH et al., 2014; SILVA et al., 2015). The particle size - expressed by the geometric mean diameter (GMD) — can influence nutrient digestibility 
and, consequently, animal performance (PARSONS et al., 2006). JACOBS \& PARSONS (2013) reported increased gizzard weight when animals were fed coarse particles of corn and whole-grain sorghum, which provided benefits to intestinal health. NAGATA et al. (2004) found nitrogen-corrected apparent metabolizable energy (AMEn) values of 3,223 and $3,279 \mathrm{kcal} / \mathrm{kg}$ for ground and whole-grain pearl millet in broilers, respectively. The AMEn coefficients of ground and whole-grain sorghum were 3,529 and $3,573 \mathrm{kcal} / \mathrm{kg}$, respectively, and ranged from 3,665 to $3,804 \mathrm{kcal} / \mathrm{kg}$ between the studied corn hybrids (results expressed on a dry-matter basis).

Chickens fed with smaller particle sizes exhibited increased excretion of gross energy, which was result of a higher passage rate from the gizzard to the duodenum and small intestine. Fine particles tend to hinder the crushing efficiency and the action of gastric juice in the gizzard and affect enzymatic action in the small intestine, ultimately affecting digestion as well as nutrient availability and absorption (SELLE et al., 2010; MANYELO et al., 2019).

Studies on the influence of different feed particle sizes have been conducted with fast-growing lines, especially involving corn, sorghum and pearl millet (BATONON-ALAVO et al., 2015; LY et al., 2015). However, it is known that breeding can interfere with the development of the intestinal tract, leading to differences in nutrient use efficiency. The present study was thus undertaken to determine the AME and AMEn values and the metabolizability coefficients of dry matter, protein and ether extract of corn, pearl millet and sorghum in different particle sizes for Label Rouge broilers.

\section{MATERIALS AND METHODS}

Two experiments were carried out and for each experiment, 140 Label Rouge ${ }^{\circledR}$ Naked Neck chicks were used in a completely randomized experimental design. The birds were randomly distributed in galvanized-steel cages equipped with linear feeders and drinkers, metal trays for excreta collection and $60-\mathrm{W}$ lamps for heating. The batteries contained five floors and divisions of 0.33 $\times 0.50 \mathrm{~m}$. Feed and water were freely available. The lighting program was $24 \mathrm{~h}$ in the first seven days, which was followed by natural light only, without artificial supplementation of light. Means $( \pm$ standard deviation) for maximum and minimum temperature were $34.13 \pm 1.41^{\circ} \mathrm{C}$ and $18.34 \pm 1.71^{\circ} \mathrm{C}$, respectively. Maximum and minimum relative humidity means were $79.47 \pm 4.75 \%$ and $33.70 \pm 9.50 \%$, respectively.
In the first experiment, 140 chicks weighing $86 \mathrm{~g}$ were allotted to five treatments (four replicates of seven birds each), and in the second experiment another 140 chicks weighing $68 \mathrm{~g}$ were distributed into four treatments (five replicates of seven birds each). The treatments consisted of a reference diet and a test diet $(60 \%$ reference diet $+40 \%$ tested feedstuff), the former being a mash commercial starter feed based on corn and soybean meal for broilers, containing $20.69 \%$ crude protein (CP), 2,999 kcal AME/kg, 0.94\% Ca, 0.67\% P and $1.26 \%$ total lysine.

The feedstuffs tested in the first experiment were coarsely ground corn, finely ground corn, wholegrain pearl millet and finely ground pearl millet. In the second experiment, whole-grain sorghum, coarsely ground sorghum and finely ground sorghum were tested.

The grains were ground in a hammer mill with a 5-mm sieve, and the differences between the coarse and fine particles were due to the number of passes through the mill. Accordingly, the grain was classified as coarsely ground when it was passed once through the mill and finely ground when passed twice. The technique described by ZANOTTO \& BELLAVER (1996) was used to determine grain particle size and the GMD and geometric standard deviation (GSD) for each feedstuff. To obtain GMD and GSD data, we used a vibratory sieving equipment and the Softgran ${ }^{\circledR}$ program developed by Embrapa Swine and Poultry.

Chicks were firstly weighed and subsequently allotted to the experimental plots, maintaining the homogeneity between the treatments. Then, they were housed from one to 22 days of life in metabolism cages equipped with drinkers, feeders, and trays for excreta collection. From one to 14 days of age, all birds received the same basal feed and at 14 days of age, they started to receive the test diets. Diets and water were available ad libitum during the experimental period.

Test diets were provided for nine days, the first four of which were used as a period of adaptation to the experimental diets and the last five for total excreta collection. The diets for each experimental unit were weighed and packed in plastic bags during the collection period. Orts were weighed to determine feed intake.

Excreta were collected twice a day to avoid fermentation. The collection trays were lined with plastic and placed under the plot floor. After the experimental period, feed and excreta samples ( $200 \mathrm{~g}$ per plot) were dried and ground for laboratory

Ciência Rural, v.51, n.12, 2021. 
analyses of dry matter (DM), nitrogen $(\mathrm{N}), \mathrm{CP}$, ether extract (EE) and gross energy (GE) according to SILVA et al. (2002).

Following the protocol described by VIEIRA et al. (2007), the above-mentioned diets and excreta results were used to estimate the metabolizability coefficients, which were determined as the amount of a nutrient ingested subtracted by the excreted amount and divided by its intake. Results were expressed in percentage terms. Both AME and AMEn were determined by using equations described by SAKOMURA et al. (2016).

The different particle sizes for each grain were analyzed separately by Student's T-test at 5\% probability to compare corn and pearl millet (Exp. 1), whereas Tukey's test at 5\% probability was applied for sorghum (Exp. 2), using SAS software (2000).

\section{RESULTS AND DISCUSSION}

Chemical composition analysis of the studied grains revealed that sorghum had the highest DM values and pearl millet the highest $\mathrm{CP}, \mathrm{EE}$ and GE values. Pearl millet showed $94.4 \%, 31.76 \%$ and $7.5 \%$ higher $\mathrm{CP}, \mathrm{EE}$ and GE contents, respectively, than corn. The $\mathrm{CP}$ and $\mathrm{EE}$ values of sorghum, in turn, were $3.61 \%$ and $21.96 \%$ higher, respectively, than those of corn, but its GE content was $1.8 \%$ lower (Table 1).

In the study led by VIEIRA et al. (2014), the results of chemical analysis showed similar, higher and lower $\mathrm{CP}$ values in corn, sorghum and pearl millet, respectively, as compared with the values found in this experiment. Results were very similar for DM and EE. The authors consider that variations greater than $10 \%$ may have a considerable impact on the formulation of the diet, requiring important corrections.
The present results for DM, CP, EE and GE values are in agreement with those described by VIEIRA et al. (2014) and ROSTAGNO et al. (2017). Some factors such as growing site and conditions, soil fertility, genetic variability of the cultivar, grain storage and processing may have an influence on the nutritional and energy values of feedstuffs, as well as affect nutrient metabolizability indices.

The energy metabolizability analyses did not reveal any difference between the grains and the different particle sizes (Table 2). In the case of corn grain, the metabolizability coefficients of dry matter (MCDM), nitrogen (MCN), and ether extract (MCEE) increased with particle size. In the case of pearl millet, there were no differences for GMD and the metabolizability variables tested. The lowest MCDM, MCN and MCEE corresponded to wholegrain sorghum.

Smaller feed particles can negatively affect processing and grinding. According to FAO (1995), 1000-grain weight is 2.5-14 g for pearl millet and 25-30 g for sorghum, which impairs endosperm exposition. Smaller particle sizes lead to higher rates of passage from the gizzard to the duodenum and small intestine, hindering the action of digestive juices in the gizzard and enzymatic action in the small intestine. Ultimately, this leads to decreased digestion efficiency and nutrient availability in chickens (NIR et al., 1995; YASAR, 2003; GEWEHR et al., 2010). The proteins and starch in the sorghum endosperm are linked to kafirins, which reduce the exposure of the protein fractions to digestion (FIALHO et al., 2002; ANTUNES et al., 2006).

Pearl millet showed the highest EE contents, but its MCEE did not differ between the particle sizes. However, larger particle sizes improved the MCEE of coarsely ground corn and

Table 1 - Geometric mean diameter (GMD), geometric standard deviation (GSD) and dry matter (DM), crude protein (CP), ether extract (EE) and gross energy (GE) contents of corn, sorghum, and pearl millet in different particle sizes.

\begin{tabular}{|c|c|c|c|c|c|c|}
\hline Feedstuff & $\mathrm{GMD}, \mu \mathrm{m}$ & GSD & DM, $\%$ & $\mathrm{CP}, \%$ & $\mathrm{EE}, \%$ & $\mathrm{GE}, \mathrm{kcal} / \mathrm{kg}$ \\
\hline Coarsely ground corn & 816 & 1.73 & \multirow{2}{*}{88.31} & \multirow{2}{*}{7.20} & \multirow{2}{*}{2.55} & \multirow{2}{*}{3996} \\
\hline Finely ground corn & 794 & 1.85 & & & & \\
\hline Whole-grain pearl millet & 1,517 & 1.92 & \multirow{2}{*}{88.68} & \multirow{2}{*}{14.0} & \multirow{2}{*}{3.36} & \multirow{2}{*}{4295} \\
\hline Finely ground pearl millet & 760 & 1.63 & & & & \\
\hline Whole-grain sorghum & 1,866 & 1.86 & \multirow{3}{*}{89.42} & \multirow{3}{*}{7.46} & \multirow{3}{*}{3.11} & \multirow{3}{*}{3924} \\
\hline Coarsely ground sorghum & 919 & 1.62 & & & & \\
\hline Finely ground sorghum & 878 & 1.72 & & & & \\
\hline
\end{tabular}

Ciência Rural, v.51, n.12, 2021. 
Table 2 - Metabolizability coefficients of dry matter (MCDM), nitrogen (MCN), ether extract (MCEE), and gross energy (MCGE) of corn, pearl millet, and sorghum in different particle sizes for Label Rouge chicks.

\begin{tabular}{|c|c|c|c|c|}
\hline Feedstuff & MCDM, \% & $\mathrm{MCN}, \%$ & MCEE, $\%$ & MCGE, \% \\
\hline Coarsely ground corn & $86.56 \pm 1.85^{(1)}$ & $75.24 \pm 4.95 \mathrm{a}$ & $84.98 \pm 1.79 \mathrm{a}$ & $87.43 \pm 2.22$ \\
\hline Finely ground corn & $83.99 \pm 1.38$ & $49.50 \pm 3.14 b$ & $67.53 \pm 2.19 b$ & $85.68 \pm 1.22$ \\
\hline $\mathrm{CV}$ & 3.80 & 12.94 & 5.35 & 3.97 \\
\hline $\mathrm{P}>\mathrm{F}$ & 0.32 & 0.007 & 0.002 & 0.53 \\
\hline Whole-grain pearl millet & $79.55 \pm 4.51$ & $45.74 \pm 9.5$ & $82.76 \pm 3.09$ & $82.53 \pm 4.44$ \\
\hline Finely ground pearl millet & $82.26 \pm 3.52$ & $48.66 \pm 8.9$ & $75.24 \pm 5.74$ & $83.91 \pm 3.50$ \\
\hline $\mathrm{CV}$ & 9.95 & 38.95 & 11.37 & 9.56 \\
\hline $\mathrm{P}>\mathrm{F}$ & 0.66 & 0.83 & 0.31 & 0.82 \\
\hline Whole-grain sorghum & $78.78 \pm 2.98 b$ & $46.14 \pm 7.84 b$ & $70.92 \pm 2.74 b$ & $80.82 \pm 2.48$ \\
\hline Coarsely ground sorghum & $88.53 \pm 0.58 \mathrm{a}$ & $87.84 \pm 4.13 \mathrm{a}$ & $88.61 \pm 2.29 \mathrm{a}$ & $87.30 \pm 0.73$ \\
\hline Finely ground sorghum & $86.03 \pm 0.83 \mathrm{a}$ & $77.25 \pm 2.17 \mathrm{a}$ & $81.12 \pm 3.21 \mathrm{ab}$ & $84.67 \pm 1.30$ \\
\hline $\mathrm{CV}$ & 3.00 & 27.4 & 7.76 & 4.06 \\
\hline $\mathrm{P}>\mathrm{F}$ & 0.05 & 0.01 & 0.01 & 0.05 \\
\hline
\end{tabular}

Means followed by distinct lowercase letters in the same column are significantly different for corn and pearl millet (Student's T-test) and for sorghum (Tukey test) at 5\% probability.

(1) Standard error of the mean.

sorghum, whereas whole-grain sorghum had 20\% lower values than its coarsely ground version (Table 2). The metabolizability coefficients of gross energy (MCGE) did not differ considerably between the different particle sizes for any of the studied grains, although other authors (VIEIRA et al. (2007) found a positive correlation between particle size and MCGE after analyzing 45 corn hybrids.

The AME and AMEn values of sorghum increased with particle size (Table 3), demonstrating better nutrient utilization as a result of a lower rate of passage from the gizzard to the small intestine (RAVINDRAN et al., 2006; AMERAH et al., 2008). The AMEn values found in sorghum agree with those described by GARCIA et al. (2006) (3206 $\mathrm{kcal} / \mathrm{kg}$ ), which were nonetheless higher than the results reported by MELLO et al. (2009) (3012 kcal/ $\mathrm{kg}$ ) in larger-particle grains and by ROSTAGNO et al. (2017) (3037 kcal/kg). The lowest AMEn (2,967 $\mathrm{kcal} / \mathrm{kg}$ ) found in this study corresponded to finely ground sorghum, this value being lower than those previously described by other authors. In the case of corn and pearl millet, particle size did not influence the AMEn values. VIEIRA et al. (2014) evaluated whole, coarsely ground and finely ground pearl millet and noted that the AMEn values increased as the particle size was reduced, which was not observed in this study.

Regardless of particle size, the AMEn values of pearl millet obtained in this study were higher than the $3189 \mathrm{kcal} / \mathrm{kg}$ found by ROSTAGNO et al. (2017). The AMEn values of corn, in turn, were lower than the $3351 \mathrm{kcal} / \mathrm{kg}$ described by GENEROSO et al. (2008) and the $3393 \mathrm{kcal} / \mathrm{kg}$ reported by NERY et al. (2007). It is important to note that ingredient processing type; bird genetics, age and line; and feedstuff inclusion level in the diet can affect the metabolizable energy values, which explains the variations in AMEn values described in different studies.

According to SANTOS et al. (2014), the use of energy by Isa Label birds is superior to that of the Cobb commercial birds tested in their experiment, which may explain the difference seen in pearl millet. For corn, the authors observed that the energy values in Isa Label were approximately $21 \%$ higher than in the Cobb line. This may explain the higher values obtained for sorghum and pearl millet, especially in larger particle sizes.

Along the same lines, SANTOS et al. (2015) found that the AME and AMEn values of corn, whole corn germ, sorghum and soybean meal in Isa 
Table 3 - Apparent metabolizable energy (AME) and nitrogen-corrected AME (AMEn) expressed on dry matter (DM) and fresh matter (FM) bases for corn, pearl millet and sorghum in different particle sizes for Label Rouge chicks.

\begin{tabular}{|c|c|c|c|c|}
\hline & AME DM & AME FM & AMEn DM & AMEn FM \\
\hline & $(\mathrm{kcal} / \mathrm{kg})$ & $(\mathrm{kcal} / \mathrm{kg})$ & $(\mathrm{kcal} / \mathrm{kg})$ & $(\mathrm{kcal} / \mathrm{kg})$ \\
\hline Coarsely ground corn & $3,649 \pm 90^{(1)}$ & $3,384 \pm 81$ & $3,530 \pm 84$ & $3,273 \pm 75$ \\
\hline Finely ground corn & $3,048 \pm 82$ & $3,265 \pm 41$ & $3,445 \pm 45$ & $3,200 \pm 36$ \\
\hline $\mathrm{CV}$ & 3.68 & 5.41 & 3.68 & 3.43 \\
\hline $\mathrm{P}>\mathrm{F}$ & 0.21 & 0.26 & 0.21 & 0.21 \\
\hline Whole-grain pearl millet & $3,685 \pm 186$ & $3,414 \pm 159$ & $3,617 \pm 171$ & $3,352 \pm 145$ \\
\hline Finely ground pearl millet & $3,654 \pm 144$ & $3,436 \pm 133$ & $3,586 \pm 131$ & $3,372 \pm 120$ \\
\hline $\mathrm{CV}$ & 9.0 & 8.54 & 8.37 & 7.91 \\
\hline $\mathrm{P}>\mathrm{F}$ & 0.90 & 0.92 & 0.45 & 0.46 \\
\hline Whole-grain sorghum & $3,364 \pm 99 a$ & $3,137 \pm 95 \mathrm{a}$ & $3,295 \pm 88 \mathrm{a}$ & $3,137 \pm 95$ \\
\hline Coarsely ground sorghum & $3,353 \pm 28 \mathrm{a}$ & $2,818 \pm 73 b$ & $3,156 \pm 28 a b$ & $3,147 \pm 23$ \\
\hline Finely ground sorghum & $3,163 \pm 50 b$ & $2,645 \pm 42 b$ & $3,024 \pm 47 b$ & $2,967 \pm 44$ \\
\hline $\mathrm{CV}$ & 4.00 & 5.40 & 3.80 & 3.91 \\
\hline $\mathrm{P}>\mathrm{F}$ & 0.09 & 0.05 & 0.02 & 0.11 \\
\hline
\end{tabular}

Means followed by distinct lowercase letters in the same column are significantly different for corn and pearl millet (Student's T-test) and for sorghum (Tukey test) at 5\% probability.

(1) Standard error of the mean.

Label and Cobb birds were very similar, with only the evaluation age (10 to 17 or 28 to 35 days of age) being a determinant of differences.

In general, thicker or medium particles can lead to increased intake and weight gain in fast-growing broilers. However, many authors obtained conflicting results (LÓPEZ et al., 2007; ZANG et al., 2009; BENEDETTI et al., 2011; ANDRADE et al., 2016; SILVA et al., 2018). MTEI et al. (2019) compared the digestibility of nutrients in fine, medium and coarse particles for laying hens (GMD \pm GSD: $477 \pm 2.5,642 \pm 2.6$ and 818 \pm 2.4 , respectively) and fast-growing chickens $(\mathrm{GMD} \pm$ GSD: $492 \pm 2.2,700 \pm 2.4$ and $912 \pm 2.4$, respectively) and found superior use in the chickens as compared with the laying hens, except for calcium and phosphorus. In the layers, the medium and coarse particles, mainly, were more efficient for the digestibility of DM, starch and GE. According to ZAEFARIAN et al. (2016), inappropriate use of particle sizes at different stages of production can result in problems related to the crushing efficiency of the gizzard and intestinal integrity.

Therefore, it is important to examine the different factors that influence the utilization of nutrients and energy by birds such as the nature of the ingredient, its particle size and the age at which the animal is evaluated, especially when considering slow-growing lines.

\section{CONCLUSION}

The supply of larger grain particles improves the metabolizability and availability of nutrients and energy in slow-growing broilers. Gains in metabolization coefficient with the use of fine and coarse grinding were, on average, $20.7 \%$ for corn and $6.6 \%$ for sorghum. Energy values increased, on average, by $7.0 \%$ in corn and $5.7 \%$ in sorghum. The metabolizability indices and energy values of pearl millet did not change.

Our results also showed that whole-grain sorghum has limited nutritional utilization for slowgrowing birds up to 22 days of age. This finding can be useful for producers, who will be able to reduce costs incurred with the grinding process.

The work was not apreciatte by Bioethics and Biossecurity Committee because it was carried out before the Law $\mathrm{n}^{\circ}$ 11.794, de 08.10.2008.

Ciência Rural, v.51, n.12, 2021. 


\section{ACKNOWLEDGEMENTS}

The authors would like to thank Universidade Federal do Tocantins and Universidade Federal de Goiás for the structure, materials and financial support, and was financed in part by the the Coordenação de Aperfeiçoamento de Pessoal de Nível Superior (CAPES), Brasil - Finance code 001”.

\section{DECLARATION OF CONFLICT OF} INTEREST

The authors declare no conflict of interest. The founding sponsors had no role in the design of the study, data collection and analysis, decision to publish, or preparation of this manuscript; in the collection, analyses, or interpretation of data; in the writing of the manuscript, and in the decision to publish the results.

\section{AUTHORS' CONTRIBUTIONS}

All authors contributed equally for the conception and writing of the manuscript. All authors critically revised and approved the final version of this manuscript.

\section{REFERENCES}

AMERAH, A. M. et al. Influence of feed particle size on the performance, energy utilization, digestive tract development, and digesta parameters of broiler starters fed wheat- or corn-based diets. Poultry Science. v.87, p.2320-2328, 2008. Available from: $<$ https://doi.org/10.3382/ps.2008-00149>. Accessed: Jun. 01, 2019. doi: 10.3382/ps.2008-00149.

ANDRADE, E.C. Effects of particle size and physical formo $f$ diets on broiler performance. Arquivo Brasileiro de Medicina Veterinária e Zootecnia, v.68, n.2, p.483-488, 2016. Available from <https://dx.doi.org/10.1590/1678-4162-8496>. Accessed in Nov 20, 2020. doi: https://dx.doi.org/10.1590/1678-4162-8496.

ANTUNES, R. C. et al. Nutritional value of sorghum grains with different endosperm textures for chicken. Arquivo Brasileiro de Medicina Veterinária e Zootecnia, v.58, p.877883, 2006. Available from: <https://doi.org/10.1590/S010209352006000500025>. Accessed: May, 30, 2019. doi: 10.1590/ S0102-09352006000500025.

BATONON-ALAVO, D.I. et al. Inclusion of sorghum, millet and cottonseed meal in broiler diets: a meta-analysis of effects on performance. Animal. v.9, p.1120-1130, 2015. Available from: $<$ https://doi.org/10.1017/S1751731115000282>. Accessed: Sept. 15, 2019. doi: 10.1017/S1751731115000282.

BENEDETTI, M.P. Corn texture and particle size in broiler diets. Brazilian Journal of Poultry Science, v.13, p.227-234, 2011. Available from: <https://www.scielo.br/pdf/rbca/v13n4/ v13n4a02.pdf>. Accessed: Nov. 20, 2020. doi: 10.1590/S1516$635 \times 2011000400002$.

CHEWNING C.G. et al. Effects of particle size and feed form on broiler performance. Journal of Applied Poultry Research, v.21, p.830-837, 2012. Available from: <https://doi.org/10.3382/ japr.2012-00553>. Accessed: Sept. 15, 2019. doi: 10.3382/ japr.2012-00553.
FAO. Introduction - Grains and their structure. In: Sorghum and millets in human nutrition. Rome: Food and Agriculture Organization of the United Nations, 1995. Online. Available from: $<$ http://www.fao.org/3/t0818e/t0818e02.htm>.

FERNANDES, E. A. et al. The use of whole grain sorghum in broiler feeds. Brazilian Journal of Poultry Science, v.15, p.217-222, 2013. Available from: $<$ https://doi.org/10.1590/S1516635X2013000300008>. Accessed: Sept. 20, 2019. doi: 10.1590/ S1516-635X2013000300008.

FIALHO, E. T. et al. Corn substituition by sorghum without tannin in piglet rations: nutrient digestibility and animal performance. Revista Brasileira de Milho e Sorgo, v.1, n.1, p.105-111, 2002. Available from: $<$ http://dx.doi.org/10.18512/1980-6477/rbms.v1n1p105-111>. Accessed: May, 30, 2019. doi: 10.18512/1980-6477/rbms.v1n1p105-111.

GARCIA, A. R. et al. Feeding of unground pearl millet to laying hens. Journal of Applied Poultry Research, v.15, p.574-578. 2006. Available from: <https://doi.org/10.1093/japr/15.4.574>. Accessed: Jun. 01, 2019. doi: 10.1093/japr/15.4.574.

GENEROSO, R. A. R. et al. Chemical and energy composition of some feeds for broiler chicks and two ages. Revista Brasileira de Zootecnia, v.37, p.1251-1256, 2008. Available from: <https://doi. org/10.1590/S1516-35982008000700016>. Accessed: May, 28, 2019. doi: 10.1590/S1516-35982008000700016.

GEWEHR, C. E. et al. Whole and ground corn in the food of brown laying hens. Archives of Veterinary Science, v.15, p.36-42, 2010. Available from: <http://dx.doi.org/10.5380/avs.v15i1.15958>. Accessed: May, 30, 2019. doi: 10.5380/avs.v15i1.15958.

JACOBS, C.; PARSONS CM. The effects of coarse ground corn, whole sorghum, and a prebiotic on growth performance, nutrient, digestibility, and cecal microbial populations in broilers fed diets with and without corn distiller drie grais with solubles. Poultry Science, Champaign, v.92, n.9, p.2347-2357, 2013. Available from: < http://dx.doi.org/10.3382/ps.2012-02928>. Accessed: Aug. 26, 2019. doi: 10.3382/ps.2012-02928.

LÓPEZ, C.A.A. Effects of physical form of ration on feed digestibility and performance of broiler chickens. Arquivo Brasileiro de Medicina Veterinária e Zootecnia, v.59, n.4, p.1006-1013, 2007. Available from <https://dx.doi.org/10.1590/ S0102-09352007000400029>. Accessed: Nov. 20, 2020. doi: 10.1590/S0102-09352007000400029.

LY, M. et al. Effects of feed form and feed particle size on growth performance, carcass characteristics and digestive tract development of broilers. Animal Nutrition, v.1, p.252-256, 2015. Available from: <https://doi.org/10.1016/j.aninu.2015.06.001>. Accessed: Sept. 15, 2019. doi: 10.1016/j.aninu.2015.06.001.

MANYELO T.G. et al. Research Report: Substitution of Zea mays by Sorghum bicolor on Performance and Gut Histo-Morphology of Ross 308 Broiler Chickens Aged 1-42 d. Journal of Applied Poultry Research, v.28, p.647-657, 2019. Available from: $<$ https://doi.org/10.3382/japr/pfz015>. Accessed: Jan. 30, 2020. doi: $10.3382 /$ japr/pfz015.

MELLO, H. H. C. et al. Metabolizable energy values of feedstuffs obtained from poultry at different ages. Revista Brasileira de Zootecnia, v.38, p.863-868, 2009. Available from: <https://doi. org/10.1590/S1516-35982009000500012>. Accessed: May, 28, 2019. doi: 10.1590/S1516-35982009000500012. 
MTEI, A W. et al. Impact of corn particle size on nutrient digestibility varies depending on bird type. Poultry Science, v.98, p.5504-5513, 2019. Available from <http://www.sciencedirect. com/science/article/pii/S0032579119457556>. Accessed: Nov. 20, 2020. doi $10.3382 / \mathrm{ps} / \mathrm{pez} 206$.

NAGATA,A.K. et al. Metabolizable energy of some energy foods for broilers, determined by metabolic assays and prediction equations. Ciência e Agrotecnologia, v.28, p.668-677, 2004. Available from: $<$ https://doi.org/10.1590/S1413-70542004000300025>. Accessed: May, 30, 20219. doi: 10.1590/S1413-70542004000300025.

NIR, H. et al. Effect of particle size on performance. 3. Grinding pelleting interactions. Poultry Science, v.74, p.771-783, 1995. Available from: <https://doi.org/10.3382/ps.0740771>. Accessed: May, 30, 2019. doi: 10.3382/ps.0740771.

PARSONS, A. S. et al. Effect of corn Particle Size and Pellet Texture on Broiler Performance in the Growing Phase. Journal of Applied Poultry Research, v.15, p.245-255, 2006. Available from: $<$ https://doi.org/10.1093/japr/15.2.245>. Accessed: Aug. 25, 2019. doi: 10.1093/japr/15.2.245

RAVINDRAN V. et al. Influence of whole wheat feeding on the development of gastrointestinal tract and performance of broiler chickens. Australian Journal of Agricultural Research, v.57, p.21-26, 2006. Available from: <https://doi.org/10.1071/ AR05098>. Accessed: Jun. 01, 2019. doi: 10.1071/AR05098.

ROSTAGNO, H. S. et al. Tabelas brasileiras para aves e suínos: composição de alimentos e exigências nutricionais. 4.ed. Viçosa, MG: Editora UFV. 2017. 488p.

SAKOMURA, N. K ROSTAGNO, H. S. Métodos de pesquisa em nutrição de monogástricos. 2. ed. Jaboticabal: FUNEP, 2016. 262p.

SANTOS, F. R. et al. Feed formulation for slow-growing broilers using metabolizable energy values of food determined with strains of slow-and-fast-growing. Arquivo Brasileiro de Medicina Veterinária e Zootecnia, v.66, p.1839-1846, 2014. Available from: <https://doi.org/10.1590/1678-6402>. Accessed: Nov. 20, 2020. doi: 10.1590/1678-6402.

SANTOS, F.R. et al. Values of metabolizable Energy and Metabolization of Nutrients for Slow- and Fast-growing Birds at Different Ages. Brazilian Journal of Poultry Science, v.17, p.517-522. Available from: <https://doi.org/10.1590/1516635X1704517-522>. Accessed: Nov 20, 2020. doi: 10.1590/1516$635 \times 1704517-522$

SAS Institute. SAS users guide: statistics. Version 8. 2. ed. Carry, 2000.

SELLE, P.H. et al. Implications of sorghum in broiler chicken nutrition. Animal Feed Science and Technology, v.156, p.57-74, 2010. Available from: <https://doi.org/10.1016/j. anifeedsci.2010.01.004>. Accessed: Jan. 30, 2020. doi: 10.1016/j. anifeedsci.2010.01.004.
SILVA, D. J. et al. Análise de alimentos: métodos químicos e biológicos. 3.ed. Viçosa: Editora UFV. 2002. 235p.

SILVA, M. C. A. et al. Effects of sorghum on broilers gastrointestinal tract. Brazilian Journal of Poultry Science, v.17, p.95-102, 2015. Available from: <https://doi.org/10.1590/1516-635x170195-102>. Accessed: Jul. 25, 2019. doi: 10.1590/1516-635x170195-102.

SILVA, P. G. Effects of processing, particle size and moisturizing of sorghum-based feeds on pellet quality and broiler production. Asian-Australasian Journal of Animal Sciences, v.31, n.1, p.98105, 2018. Available from doi: 10.5713/ajas.17.0473. Accessed: Nov. 20, 2020. doi: 10.5713/ajas.17.0473.

SINGH, Y. et al. Whole grain feeding: Methodologies and effects on performance, digestive tract development and nutrient utilisation of poultry. Animal Feed Science and Technology, v.190, p.1-18, 2014. Available from: <https://doi.org/10.1016/j. anifeedsci.2014.01.010>. Accessed: Sept. 20, 2019. doi: 10.1016/j. anifeedsci.2014.01.010

VIEIRA, R. A. et al. Chemical composition and apparent metabolized energy value of some energy feedstuffs for broiler.

Revista Brasileira de Agropecuária Sustentável, v.4, n.2, 2014. Available from: <https://doi.org/10.21206/rbas.v4i2.261>. Accessed: May, 30, 2019. doi: 10.21206/rbas.v4i2.261.

VIEIRA, R. O. et al. Chemical composition and metabolizable energy of corn hybrids for broilers. Revista Brasileira de Zootecnia, v.36, p.832-838, 2007. Available from: $<$ https://doi. org/10.1590/S1516-35982007000400012>. Accessed: May, 30, 2019. doi: $10.1590 / \mathrm{S} 1516-35982007000400012$.

YASAR, S. Performance, gut size and ileal digesta viscosity of broiler chickens fed with a whole wheat added diet and the diets with different wheat particle sizes. International Journal of Poultry Science, v.2, p.75-82, 2003. doi: 10.3923/ijps.2003.75.82.

ZAEFARIAN, F. Particle size and feed form in broiler diets: impact on gastrointestinal tract development and gut health, World's Poultry Science Journal, v.72, p.277-290, 2016. Available from: $<$ https://www.tandfonline.com/doi/abs/10.1017/S0043933916 000222? journalCode $=$ twps20>. Accessed: Nov. 20, 2020. doi: $10.1017 / \mathrm{S} 0043933916000222$.

ZANG, J. et al. Effects of Feed Particle Size and Feed Form on Growth Performance, Nutrient Metabolizability and Intestinal Morphology in Broiler Chickens. Asian-australasian Journal of Animal Sciences, v.22, p.107-112, 2009. Available from $<$ doi:10.5713/AJAS.2009.80352>. Accessed: Nov 20, 2020. doi: 10.5713/AJAS.2009.80352.

ZANOTTO, D. L.; BELLAVER, C. Método de determinação da granulometria de ingredientes para uso em rações de suínos e aves. Embrapa Suínos e Aves. (Comunicado Técnico), n.215, 1996, 5p. Online. Available from: http://www.cnpsa.embrapa.br/ sgc/sgc_publicacoes/cot215.pdf. 